\title{
Developmental changes in foraging-predator avoidance trade-offs in larval lumpfish Cyclopterus lumpus
}

\author{
P. James Williams, Joseph A. Brown \\ Department of Biology/Ocean Sciences Centre, Memorial University of Newioundland, St. John's, Newfoundland, \\ Canada A1B 3X9
}

\begin{abstract}
We exposed 5,8,12 and $15 \mathrm{wk}$ old larval lumpfish Cyclopterus lumpus L. to a predator (three-spined stickleback Gasterosteus aculeatus) in order to test whether or not lumpfish would reduce foraging in order to reduce the probability of being attacked. We found that 5 to $12 \mathrm{wk}$ old larvae increased the time they spent clinging to a surface in the presence of the predator, thereby trading-off time available for foraging in order to reduce the probability of attack. Overall, fewer fish fed in the presence of a predator, and of the fish that did feed, $12 \mathrm{wk}$ old lumpfish also showed a significant decrease in feeding rate (bites per minute swimming) in the presence of a predator. The behaviourial anti-predator defences displayed by the lumpfish would be effective in the environment in which the larval lumpfish are naturally found. We discuss the applicability of the results of this study to other larval fish.
\end{abstract}

\section{INTRODUCTION}

Predation can be broken down into the following sequence of events: encounter, attack, and capture of prey (modified from O'Brien 1979). Anti-predator defences that have evolved in prey organisms act to interrupt this sequence at different steps (Endler 1986 , Sih 1987). For example, prey may decrease the probability of encounters with predators by hiding, by avoiding areas of high predator density, or by being cryptically coloured (Mittelbach 1981, Endler 1986, Main 1987, Sih 1987, Pierce 1988). Once an encounter has taken place, anti-predator defences that reduce the probability of attack become important, such as cessation of movement, unpalatability, mimicry of organisms that are poisonous or unpalatable, or flight to a refuge (Endler 1986). Finally, once an attack is initiated by a predator, defences act to reduce the probability of capture. This last type of defence includes rapid evasive movements and flight, spines or plates that make handling difficult, and active fighting (Helfman 1986, Sih 1987). In order to properly assess the anti-predator capabilities of an organism, all 3 types of anti-predator defences should be evaluated.
In the last decade an increasing number of predation studies have used larval fish as prey, and virtually all of these studies have only examined anti-predator defences that operate at the last step in the predation sequence, that is, defences that reduce the probability of capture given an attack by a predator (Miller et al. 1988, Fuiman 1989, Margulies 1989, 1990, but see Blaxter \& Fuiman 1990). However, as pointed out by Endler (1986), defences that operate earlier in the sequence are more efficient, due to a greater probability that the predation sequence will be interrupted without injury to the prey. It seems likely that larval fish should possess and utilize anti-predator defences that reduce the probability of attack.

Probably the simplest anti-predator defence that reduces the probability of attack is cessation of movement, or freezing. Such freezing behaviour has been reported in many groups of animals (Herzog \& Burghardt 1974, Zaret 1980, Dill 1987, Sih 1987, Gerkema \& Verhulst 1990) including fish (Brown 1984, Wootton 1984, Fitzgerald \& Wootton 1986, Helfman 1986, Huntingford et. al 1988, Radabaugh 1989). Freezing is an effective anti-predator defence because most predators key on movement as their first contact with prey (Ware 
1973, O'Brien 1979, Stein 1979, Prejs 1987), or use movement as a criterion for deciding whether or not to attack an object they are presently inspecting (Orr 1989).

All anti-predator defences have costs associated with them (Milinski \& Heller 1978, Dill \& Fraser 1984, Lima et. al 1985, Dill 1987, Sih 1987). Probably the most important cost associated with cessation of movement is reduced foraging. For a larval fish, a reduction in time available for foraging could represent a substantial cost due to the limited energy stores many larval fish possess. Therefore, it would seem adaptive for larval fish to be able to assess the level of predation threat and respond so as to minimize associated costs. Studies have demonstrated this ability in juvenile and adult fish, where the prey varied their response to potential predators depending upon the prey's hunger level (Dill \& Fraser 1984, Magnhagen 1988), behaviour of the predator (Sih 1987, Helfman 1989), and predatorprey size ratio (Stein \& Magnuson 1976, Sih 1980, 1984, Brown 1984, Werner \& Gilliam 1984, Main 1987, Prejs 1987). Other studies have shown that prey fish not only spend less time foraging in the presence of a predator, but in addition the effectiveness of their foraging decreased (Milinski \& Heller 1978, Fraser \& Huntingford 1986, Milinski 1986). This effect has been attributed to increased vigilance by the prey fish.

In this study we tested larval lumpfish Cyclopterus lumpus to determine whether or nat they would use the freezing response to reduce the probability of attack by a predator Larval lumpfish possess an adhesive disk that allows them to cling to surfaces (Brown 1986). This adaptation should enhance the effectiveness of a freezing response by anchoring a larva in place. Specifically, our objectives were to determine: (1) whether or not larval lumpfish use a freezing response, and thus tradeoff foraging time, in order to reduce the probability of attack by a potential predator; (2) whether or not hunger level of the lumpfish affects their willingness to trade off foraging time against the threat of attack by a predator; and (3) whether or not the response of larval lumpfish to a predator changes with ontogeny

\section{MATERIALS AND METHODS}

Fertilized lumpfish eggs were collected by divers in Conception Bay, Newfoundland, Canada, and incubated in ambient seawater until hatch. Larvae were held in an $80 \mathrm{l}$ aquarium and fed live Artemia nauplii once a day at a density of ca 300 nauplii $1^{-1}$. We have observed that a peak in mortality of larval lumpish occurs at ca 4 wk post-hatch. Accordingly, in this study we waited until after this peak had occurred, and then placed ca 400 randomly selected larvae into each of four 401 aquaria. Artemia were added once a day to these 4 aquaria, at 2 food density levels. Two aquaria received enough Artemia to produce an immediate prey density of ca 100 nauplii $1^{-1}$ (low food treatment). while the other 2 aquaria received Artemia to produce an immediate food density of ca 250 nauplii $\mathrm{l}^{-1}$ (high food treatment). Testing began after the larvae had been exposed to the food levels for a period of $1 \mathrm{wk}$.

The predators used in this study were three-spined sticklebacks Gasterosteus aculeatus. Three $6 \mathrm{~cm}$ sticklebacks were maintained in separate compartments of a $40 \mathrm{l}$ saltwater aquarium. In preliminary trials, hungry sticklebacks captured and consumed 5 wk old lumpfish larvae; consequently sticklebacks were fed to satiation with capelin Mallotus villosus eggs prior to each experiment.

At Week 5 post hatch, testing began. Two groups of 15 larvae were selected at random from each of the 4 holding aquaria, yielding 8 groups of 15 larvae (4 high food, 4 low food). Each group was then placed into a separate opaque plastic container $(23 \times 23 \times 8 \mathrm{~cm}$, containing ca 2 l of seawater) floating in a wet bench. Two test containers from each food level were randomly designated to receive a satiated predator during the experiment. After $1 \mathrm{~h}$ of acclimatization, one container, chosen at random, was gently moved into position under a suspended video camera. Each experimental trial (i.e. each test container) began with 1 min of filming with no food or predator present. This was followed by the introduction of food $\left(250\right.$ Artemia $^{-1}$ for a high food container, 100 Artemia $^{-1}$ for a low food container) to the container, and, if designated, a satiated stickleback. Video recording continued for an additional $10 \mathrm{~min}$, after which another test container was moved into position and the same procedure followed. Larvae were used in only one trial. One experiment was carried out at ca 3 wk intervals at Weeks 5,8 , 12 , and 15 post-hatch. The experiment was terminated after Week 15 because the larvae had increased in size to a point where they were no longer responding to the predator.

The behaviour of individual larvae was recorded from the video tapes using an event recorder. The variables extracted from the video were the time ( $s$, between 0 and 120 ) spent clinging to a surface (i.e. freezing) and the number of bites each individual lumpfish performed (see Brown 1986 for definition of bites). Because capture success of lumpfish larvae feeding on Artemia nauplii is close to $100 \%$ after the first 2 wk post-hatch (Brown 1986), we feel that the measure used was a good indicator of feeding. Lengths of each individual larva were obtained from the video tapes using an image analysis system.

To reduce viewing time, we sampled the video recordings. To determine which segment of the trial 
would make up the sample, we viewed the entire trial for all 4 of the low food treatments in Week 5 and recorded total time clinging and number of bites performed by each lumpfish. These variables exhibited the most variation during the initial 3 min of each trial, with no substantial changes during the last $7 \mathrm{~min}$. We selected the 2 min segment from Minute 5 to Minute 7 for analysis, thereby focusing on the final response of the larvae to the experimental situation.

The experimental design for each week was a $2 \times 2$ factorial experiment, with factors 'food' (low or high) and factor 'predator' (present or absent), with each food-predator combination duplicated. Each experiment (Weeks 5, 8, 12 and 15) was analyzed separately. In the analysis of time spent clinging, larval length was included as a covariable to allow examination of the effects of food and predator after length effects had been removed. This data set was analyzed using the GLM procedure in SAS (SAS 1988). The residuals were tested for normality using the Shapiro-Wilk statistic, and plots of the residuals versus the predicted values were examined to detect violations of the assumptions of independence and constant variance. Consequently, time clinging was converted to a proportion of the total 2 min, and an arc-sine transformation performed. This procedure restored normality to the data from Weeks 5 , 8 , and 12 , but not the data from Week 15 . The departures from normality in Week 15 were due to a large number of observations at the boundaries (i.e. 0 and $120 \mathrm{~s}$ ). Here we applied a probit transformation, which restored normality. The use of different transformations was acceptable because we analyzed each week's data separately.

In the analysis of the feeding data, the number of larvae that performed any bites was modelled as a binomial variate, with the number of trials being the total number of larvae in that food-predator combination (for example, 7 of 30 larvae fed in the low-food nopredator trial in Week 5). The model was fitted using a Generalized Linear Model (McCullagh \& Nelder 1989) as implemented in the computer software GLIM (Payne 1987). In order to assess the potential for confounding length effects in this analysis, we further compared the lengths of the lumpfish between each treatment combination (low food without predator, low food with predator, etc.) within each week, using the GLM procedure in SAS. Finally, to determine whether or not larval lumpfish were more vigilant when in the presence of a predator, we calculated feeding rate/time swimming for each larva that fed during the trial period by dividing the number of bites performed by that larva by the total number of seconds the larva was swimming (i.e. not clinging), and compared these rates using an ANOVA (SAS procedure GLM). The level of significance for all statistical tests was set at 0.05 .

\section{RESULTS}

When introduced into a test container, the stickleback would usually remain motionless for the first minute of the trial. During this time, the lumpfish would often perform what appeared to be a form of predator inspection (Wootton 1984), consisting of a group of lumpfish swimming to within $10 \mathrm{~cm}$ of the stickleback, and remaining, sometimes clinging, all oriented with heads towards the predator. This behaviour was not repeated after the stickleback began to move about the container. After the initial inspection period, most larvae reacted to the approach of the predator (within ca $10 \mathrm{~cm}$ ), by clinging to the bottom or side of the container. Approximately $10 \%$ of the lumpfish would quickly swim to a corner of the container and resume clinging immediately after the stickleback moved past. There were no obvious differences among experimental trials in the amount of time the predators spent swimming or motionless.

All of the interaction terms in the analysis of time clinging to a surface were not significant (Table 1). In the analysis of the number of fish feeding all of the interaction terms except that of Week 15 were not significant (Table 2). In Week 5 post-hatch, the presence of a predator significantly increased the time larval lumpfish spent clinging to a surface (Fig. 1, Table 1). In Week 8, the categorical data (Fig. 1) does show that the lumpfish spent more time clinging in the presence of a predator; however, the predator term from the analysis only approaches significance at $\mathrm{p}=0.066$. The $12 \mathrm{wk}$ old lumpfish spent significantly more time clinging in the presence of a predator. By Week 15, the presence of a predator clearly did not increase time clinging. The analysis of the number of fish feeding (Table 2, Fig. 2) shows similar trends to the analysis of time clinging. The presence of a predator significantly decreased the proportion of fish feeding in Weeks 5,8 and 12 post-hatch. In addition, there was a significant food effect in Week 12; specifically (Fig. 2) more fish from the high food treatment fed during the experiment than from the low food treatment. The significant foodpredator interaction term in Week 15 requires separate interpretation of the main effects. Examination of Fig. 2 clearly illustrates this interaction in that the presence of a predator did not seem to affect the number of larvae from the high food treatment that fed during the trial, whereas the presence of a predator decreased the number of larvae feeding from the low food treatment. Finally, the presence of a predator only significantly decreased the feeding rate (bites per time swimming) for 12 wk old larvae $(p=0.3341,0.7014,0.0414$, and 0.8782 for Weeks $5,8,12$ and 15 respectively). There were no significant differences in mean length $(\mathrm{mm})$ of the lumpfish between treatments in any of the experi- 
Table 1. Cyclopterus lumpus. Results of analysis of variance of the effects of food level and predator presence on the time larval lumpfish spent clinging to a surface. Degrees of freedom were determined using Satterthwaite's approximation (e.g. Snedecor \& Cochran 1980). Length was included as a covariate in all models

\begin{tabular}{|c|c|c|c|c|c|}
\hline & Source & df num. & df den & $F$-value & $\mathrm{p}>F$ \\
\hline Week 5 & $\begin{array}{l}\text { Food } \\
\text { Predator } \\
\text { Food } \times \text { Pred }\end{array}$ & $\begin{array}{l}1 \\
1 \\
1\end{array}$ & $\begin{array}{l}3.88 \\
4.08 \\
3.91\end{array}$ & $\begin{array}{r}2.355 \\
20.020 \\
3.882\end{array}$ & $\begin{array}{l}0.2019 \\
0.0106 \\
0.1218\end{array}$ \\
\hline Week 8 & $\begin{array}{l}\text { Food } \\
\text { Predator } \\
\text { Food } \times \text { Pred. }\end{array}$ & $\begin{array}{l}1 \\
1 \\
1\end{array}$ & $\begin{array}{l}4.00 \\
4.04 \\
4.01\end{array}$ & $\begin{array}{l}0.013 \\
6.209 \\
0.842\end{array}$ & $\begin{array}{l}0.9144 \\
0.0667 \\
0.4106\end{array}$ \\
\hline Week 12 & $\begin{array}{l}\text { Food } \\
\text { Predator } \\
\text { Food } \times \text { Pred. }\end{array}$ & $\begin{array}{l}1 \\
1 \\
1\end{array}$ & $\begin{array}{l}3.98 \\
4.02 \\
3.97\end{array}$ & $\begin{array}{r}0.333 \\
12.345 \\
0.000\end{array}$ & $\begin{array}{l}0.5950 \\
0.0244 \\
0.9844\end{array}$ \\
\hline Week 15 & $\begin{array}{l}\text { Food } \\
\text { Predator } \\
\text { Food } \times \text { Pred. }\end{array}$ & $\begin{array}{l}1 \\
1 \\
1\end{array}$ & $\begin{array}{l}4.02 \\
4.00 \\
4.03\end{array}$ & $\begin{array}{l}0.763 \\
0.163 \\
0.242\end{array}$ & $\begin{array}{l}0.4315 \\
0.7066 \\
0.6485\end{array}$ \\
\hline
\end{tabular}

Table 2. Cyclopterus lumpus. Results of GLIM procedure on the effects of food level and predator presence on the number of larval lumpfish feeding

\begin{tabular}{|clccc|}
\hline & Terms & Observed chi-square & df & p \\
\hline \multirow{2}{*}{ Week 5 } & Food & 0.4677 & 1 & 0.49405 \\
& Predator & 12.2400 & 1 & 0.00047 \\
& Food $\times$ Pred. & 2.8360 & 1 & 0.09217 \\
Week 8 & Food & 1.1790 & 1 & 0.27756 \\
& Predator & 14.4500 & 1 & 0.00014 \\
Week 12 & Food $\times$ Pred. & 0.1959 & 1 & 0.65805 \\
& Food & 14.0500 & 1 & 0.00018 \\
Wredator & Food $\times$ Pred. & 31.3200 & 1 & 0.00000 \\
& Food 15 & 2.8151 & 1 & 0.09338 \\
& Predator & 0.0000 & 1 & 1.00000 \\
Fignificant at 0.05 level & 4.5950 & 1 & 0.03207 \\
$\cdots$
\end{tabular}

ments $(p=0.1461,0.1408,0.2660$, and 0.1248 for Weeks 5, 8, 12, and 15 respectively).

\section{DISCUSSION}

In contrast to Weeks 5 to 12,15 wk old larvae no longer significantly increased time spent clinging in the presence of a predator. One explanation for this is that by Week 15, clinging has been dropped from the behaviourial repertoire as an anti-predator defence; however, we have found that disturbances in holding aquaria usually elicit clinging by larval, juvenile and even adult lumpfish. Assuming that the cling behaviour was still available as an anti-predator defence, the fact that it was not used in the presence of a stickleback may indicate that these larvae had reached a size at which they were no longer vulnerable to the predator. The mean size by Week 15 was 15.25 mm, which represents ca $25 \%$ of the total body length of the predator. Prejs (1987) cited $40 \%$ of body length as an upper limit of prey size for most freshwater piscivorous teleosts, but considering that sticklebacks possess a relatively small mouth, the $15 \mathrm{wk}$ old larvae were probably in little danger of being eaten.

An obvious, important cost associated with the freezing behaviour in larval lumpfish is reduced foraging. In our study, the increase in the time larvae spent clinging 

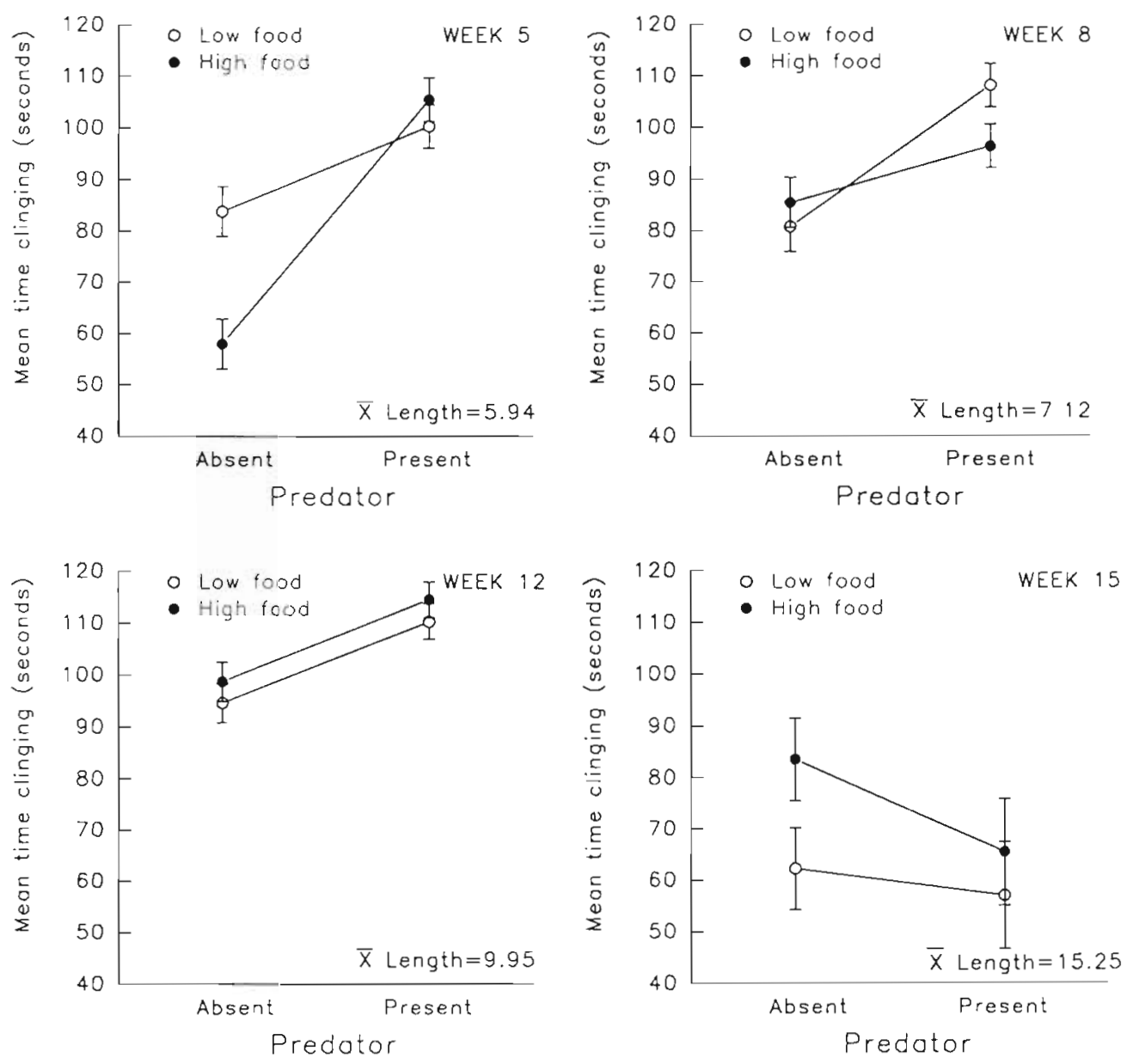

Fig. 1. Cyclopterus lumpus. Mean ( $\pm 1 \mathrm{SE}$ ) time larval lumpfish spent clinging in the presence and absence of a predator. Data are presented with respect to larval age in weeks. Mean lengths of larvae are presented in $\mathrm{mm}$

in the presence of a predator was echoed by a significant decrease in the number of larvae feeding. In another study, Brown (1986) demonstrated that larval lumpfish are able to feed from the cling position, how ever food levels in those experiments were an order of magnitude higher than in this study. In the present study, very few larvae were observed performing bites while clinging to a surface, even in the high food treatment. Therefore, increased time clinging by the lumpfish probably reduced their encounter rate with their prey, resulting in reduced opportunity to forage. Magnhagen (1988) and Prejs (1987) found evidence of decreased foraging by small fish in the presence of predators, and both authors attributed this reduction in foraging to the increased danger of being detected by predators when moving.

Both theoretical (Mangel \& Clark 1986, McNamara \& Houston 1987) and experimental (Dill \& Fraser 1984, Milinski 1986, Magnhagen 1988) studies indicate that an increased need for food should render an animal willing to accept a greater risk in order to forage.
However, in our experiment, we were unable to show any effect of hunger level on the willingness of larval lumpfish to accept risk of attack in order to forage. In terms of actual foraging, the only significant food effect occurred in Week 12, where significantly fewer larvae from the low food treatment foraged than did larvae from the high food treatment, a result that is opposite to what we might have predicted. Similarly, 15 wk old larvae from the low food treatment responded to the presence of a predator by reducing their feeding, whereas the presence of a predator did not affect the larvae from the high food treatment. Possibly the differential in food levels used in this study was not sufficient to show this effect, as Brown (1986) found good survival when larval lumpfish were fed 100 prey $\mathrm{l}^{-1}$. Had we utilized starved versus not starved groups as in Magnhagen (1988) we may have observed differences.

The anti-predator defences displayed by larval lumpfish in this study would probably be effective in the natural environment. Lumpfish spend the first year of life in the upper meter of the water column (Scott \& 

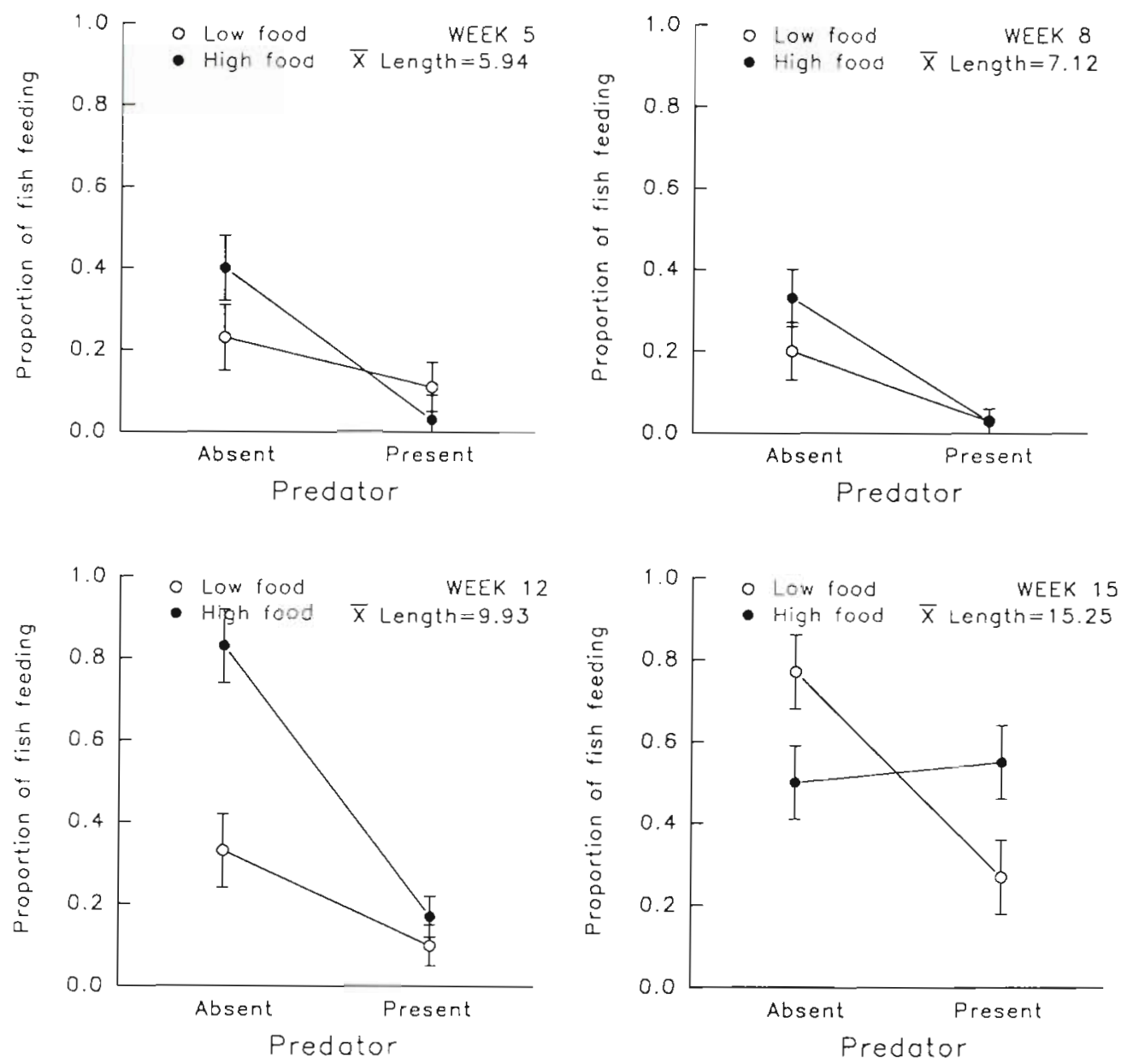

Fig. 2. Cyclopterus lumpus. Proportion of the total number of larval lumpish feeding in the presence and absence of a predator. Data are presented with respect to larval age in weeks. Mean lengths of larvae are presented in $\mathrm{mm}$

Scott 1988), despite possessing a ventral adhesive disk, an adaptation that seems to favour an epibenthic existence. Daborn \& Gregory (1983) found relatively high numbers of larval lumpfish up to $50 \mathrm{~mm}$ in length in the upper $0.5 \mathrm{~m}$ of the macrotidal Bay of Fundy, where they are often associated with masses of floating seaweed (Gregory \& Daborn 1982). Association with floating seaweed would allow larval lumpfish to forage up in the plankton-rich pelagic zone, yet still be able to reduce the probability of attack by predators by clinging to the weed when a predator was detected. In areas that do not have large collections of floating seaweed, the larval lumpfish probably frequent areas closer to shore where they may seek refuge on the bottom or in and around attached seaweed.

Most pelagic larval fish do not possess a ventral adhesive disk as larval lumpfish do, however no complex morphological adaptations are required for a simple freezing response to the threat of a potential predator. In fact, the effectiveness of a freezing response by larval fish should be enhanced because of their small size and lack of pigmentation in many species. Blaxter \& Fuiman (1989) suggested that reduced activity or movement might reduce the number of attacks on smaller pelagic larvae by fish predators, and Bailey \& Yen (1983) proposed the same strategy for pelagic hake larvae to reduce the number of attacks by a carnivorous marine copepod. Most of the research dealing with predation and larval fish has concentrated on the last step in the predation sequence, testing the ability of the larvae to escape actual attacks by predators. We believe that further investigation is needed into antipredator defences other species of pelagic larval fish may use to reduce the probability of attacks by predators.

Acknowiedgements. We thank Donna Somerton, who maintained the holding aquaria and did all of the actual filming. Rod Taylor extracted much of the data from the video tapes. Chris Bajdik provided invaluable statistical advice. Vytenis Gotceitas and Pierre Pepin provided editorial suggestions. 


\section{LITERATURE CITED}

Bailey, K. M., Yen, J. (1983). Predation by a carnivorous marine copepod, Euchaeta elongata Esterly, on eggs and larvae of the Pacific Hake, Merluccius productus. J. Plankton Res. 5: 71-82

Blaxter, J. H. S., Fuiman, L. A. (1990). The role of the sensory systems of herring larvae in evading predatory fishes. $J$. mar Biol. Ass. U.K. 70: 413-427

Brown, J. A. (1984). Parental care and the ontogeny of predator-avoidance in two species of centrarchid fish. Anim. Behav. 32: 113-119

Brown, J. A. (1986). The development of feeding behaviour in the lumpfish, Cyclopterus Iumpus. J. Fish Biol. 29 (Suppl A): $171-178$

Daborn, G. R., Gregory, R. S. (1983). Occurrence, distribution, and feeding habits of juvenile lumpfish. Cyclopterus lumpus L. in the Bay of Fundy. Can. J. Zool. 61: 797-80

Dill, L. M. (1987). Animal decision making and its ecological consequences: the future of aquatic ecology and behaviour. Can. J. Zool. 65: 803-811

Dill, L. M., Fraser, A. H. G. (1984). Risk of predation and the feeding behaviour of juvenile coho salmon (Oncorhynchus kisutch). Behav. Ecol. Sociobiol. 16: 65-71

Endler, J. A. (1986). Defense against predators. In: Feder, M. E., Lauder, G. V. (eds.) Predator-prey relationships. University of Chicago Press, Chicago and London, p. 109-134

Fitzgerald, G. J., Wootton, R. J. (1986). Behavioural ecology of sticklebacks. In: Pitcher, T. J. (ed.) The behaviour of teleost fishes. The Johns Hopkins University Press, Maryland, p. $409-432$

Fraser, D. F., Huntingford, F. A. (1986). Feeding and avoiding predation hazard: the behavioural response of the prey. Ethology 73: 56-68

Fuiman, L. A. (1989). Vulnerability of Atlantic herring larvae to predation by yearling herring. Mar Ecol. Prog. Ser. 51: 291-299

Gerkema, M. P., Verhulst, S. (1990). Warning against an unseen predator: a functional aspect of synchronous feeding in the common vole, Microtus arvalis. Anim. Behav. 40 $1169-1178$

Gregory, R. S., Daborn, G. R. (1982). Notes on adult lumpfish Cyclopterus lumpus L. from the Bay of Fundy. Proc. N.S. Inst. Sci. 32: 321-326

Helfman, G. S. (1986). Behavioural responses of prey fishes during predator-prey interactions. In: Feder, M. E., Lauder, G. V. (eds.) Predator-prey relationships. University of Chicago Press, London, p. 135-156

Helfman, G. S. (1989). Threat-sensitive predator avoidance in damselfish-trumpetfish interactions. Behav. Ecol. Sociobiol. 24: $47-58$

Herzog, H. A., Burghardt, G. M. (1974). Prey movement and predatory behaviour of juvenile western yellow-bellied racers, Coluber constrictor mormon. Herpetologica 30: 285-289

Huntingford, F. A., Metcalfe, N. B., Thorpe, J. E. (1988). Choice of feeding station in Atlantic Salmon, Salmo salar, parr: effects of predation risk, season and life history strategy. J. Fish. Biol. 33: 917-924

Lima, S. L., Valone, T. J., Caraco, T (1985). Foraging effeciency-predation risk trade-off in the grey squirrel. Anim. Behav. 33: 155-165

Magnhagen, C. (1988). Changes in foraging as a response to predation risk in two gobiid fish species, Pomatoschistus minutus and Cobius niger. Mar. Ecol. Prog. Ser. 49: $21-26$
Main, K. L. (1987). Predator avoidance in seagrass meadows: prey behaviour, microhabitat selection, and cryptic coloration. Ecology 68: 170-180

Mangel, M., Clark, C. W. (1986). Towards a unified foraging theory. Ecology 67: 1127-1138

Margulies, D. (1989). Size-specific vulnerability to predation and sensory system development of white seabass, Atractoscion nobilis, larvae. Fish. Bull. U.S. 87: 537-552

Margulies, D. (1990). Vulnerability of larval white perch, Morone americana, to fish predation. Environ. Biol. Fish. 27: $187-200$

McCullagh, P., Nelder, J. A. (1989). Generalized linear models, 2nd edn. Chapman and Hall, London

McNamara, J. M., Houston, A. I. (1987). Starvation and predation as factors limiting population size. Ecology 68 : 1515-1519

Milinski, M. (1986). Constraints placed by predators on feeding behaviour. In: Pitcher, T. J. (ed.) The behaviour of teleost fishes. Croom Helm, London, p. 236-252

Milinski, M., Heller, R. (1978). Influence of a predator on the optimal foraging behaviour of sticklebacks (Gasterosteus aculeatus L.). Nature, Lond. 275: 642-644

Miller, T. J., Crowder, L. B., Rice, J. A., Marschall, E. A. (1988). Larval size and recruitment mechanisms in fishes: towards a conceptual framework. Can. J. Fish. Aquat. Sci. 45: $1657-1670$

Mittelbach, G. G. (1981), Foraging effeciency and body size: a study of optimal diet and habitat use by bluegills. Ecology 62: $1370-1386$

O'Brien, W. J. (1979). The predator-prey interaction of planktivorous fish and zooplankton. Am. Sci. 67: 572-581

Orr, J. W (1989). Feeding behaviour of the green-breast darter, Etheostoma jordani (Percidae; Etheostomatini). Copeia 1: 202-206

Payne, C. D. (ed.) (1987). The GLIM System Release 3.77 Manual edition 2. NAG Oxford

Pierce, C. L. (1988). Predator avoidance, microhabitat shift, and risk-sensitive foraging in larval dragonflies. Oecologia (Berl.) 77: 81-90

Prejs, A. (1987). Risk of predation and feeding rate in tropical freshwater fishes: field evidence. Oecologia (Berl.) 72 259-262

Radabaugh, D. C. (1989). Seasonal colour changes and shifting anti-predator tactics in darters. J. Fish. Biol. 34 $679-685$

SAS Institute (1988). SAS/STAT user's guide, release 6.03 edition. SAS institute Inc., Cary, N. Carolina

Scott, W. B., Scott, M. G. (1988). Atlantic fishes of Canada Can. Bull. Fish. Aquat. Sci. 219

Sih, A. (1980). Optimal behaviour: can foragers balance two conflicting demands? Science 210: 1041-1043

Sih, A. (1984). The behavioural response race between predator and prey. Am. Nat. 123: 143-150

Sih, A. (1987). Predators and prey lifestyles: an evolutionary and ecological overview. In: Kerfoot, W C., Sih, A. (eds.) Predation: direct and indirect impacts on aquatic communities. University Press New England, Hanover, p. 203-224

Snedecor, G. W., Cochran, W.G. (1980). Statistical methods. Iowa State University Press, Ames

Stein, R. A. (1979). Behavioural response of prey to fish predators. In: Stroud, R. H., Clepper, H. (eds.) Predator-prey systems in fisheries management. Sport Fishing Institute, Washington, D. C., p. 343-353

Stein, R. A., Magnuson, J. J. (1976). Behavioural response of cray-fish to a fish predator. Ecology 57: 751-761

Ware, D. M. (1973). Risk of epibenthic prey to predation by 
rainbow trout (Salmo gairdneri). J. Fish. Res. Bd Can. 30: $787-797$

Werner, E. E., Gilliam, J. F. (1984). The ontogenetic niche and species interactions in size-structured populations. Ann. Rev. Ecol. Syst. 15: 393-425

This article was submitted to the editor
Wootton, R. J. (1984). The functional biology of sticklebacks. Croom Helm, London

Zaret, T M. (1980). Predation and freshwater communities. Yale University Press, New Haven and London

Manuscript first received: April 9, 1990

Revised version accepted: June 28, 1991 